\title{
Does the Prosperity Level of States Affect Participation in Trade
}

\section{Unions? A Quantitative Research}

\author{
Nickolaos Giovanis ${ }^{1 *}$ \\ ${ }^{1}$ Department of Business Administration, Technological Educational Institute Of Central Macedonia \\ Terma Magnisias Street, Greece \\ *Nickolaos Giovanis, E-mail: ng@teicm.gr
}

Received: October 21, 2016 Accepted: Novermber 6, 2016 Online Published: Novermber 11, 2016

doi:10.22158/rem.v1n2p152

URL: http://dx.doi.org/10.22158/rem.v1n2p152

\begin{abstract}
International differences in wage inequality remain a reality, despite efforts of negotiations and demands of the unions and contrary to the will of international organizations and associations for an international minimum wage. At the same time, the fall in wages and, specifically in minimum wages, combined with the decline of unionization are facts that seem connected.

This article presents the results of a quantitative research-using the Mann-Whitney non-parametric test and the linear bivariate correlation - which examines the potential connection between the Gross Domestic Product and union density in 33 member-states of the OECD, while examining the type of the correlation between them. The research results showed that high Gross Domestic Product is directly proportional to the size of union density and that there is a positive correlation between the two.
\end{abstract}

\section{Keywords}

union density, Gross Domestic Product, minimum wage, wage inequality, collective bargaining

\section{Introduction}

The reasons why people are organized in unions have many a time been the result of research (Buttigieg et al., 2008). The decline of trade unionization in all states is also true (Kaufman, 2008), as it is also true that there is a fall of GDP and that labour relations have worsened (Piore, 2011). However, what has not been sufficiently clarified is whether or not there is a two-way relationship between GDP and union density.

This exploratory proposal raises, in turn, another question: Which countries are more active in trade unionization? Do they have robust or weaker economies? What is the relationship between these two facts, if indeed they are related? When GDP values rise, union density rates rise too or when GDP values fall, union density rates fall too, and we thus have a positive correlation. On the contrary, when union density rates fall GDP values increase and vice versa and we thus have a negative correlation. 
Finally there is a chance that the two are not related at all, namely when GDP values increase they are not "followed" by union density rates, neither upwards nor downwards, hence there is no correlation between the two.

According to Naticchioni et al. (2008) in America, a parallel decline in minimum wages and in unionization is observed. These two facts seem to adversely affect underpaid employees and mainly, unskilled staff and young people.

In the context of these exploratory questions to be answered, some other concerns also emerge. Does, for instance, a good national standard of living make workers active unionists? Literature and researches have frequently argued that the establishment of a single transnational minimum wage would normalize differences (Prosser, 2014) and would provide potential development in weaker economies (Fanti \& Gori, 2010).

At times, many scholars have argued that wages and, generally the earnings of workers are the result of demands (Williams et al., 2013; Bosch, 2015) and it might therefore argued that when a state has a high level of unionization it is expected to have better paid workers and therefore higher GDP.

A section that should also be explored is the issue of productivity. Economies with high productivity have better financial results (Benoit et al., 2011) and therefore higher GDP is observed compared to countries with respectively low productivity. How is this big difference in wages explained? Possibly a wage decentralization would be necessary. Moreover, the role of the state is, in many cases, crucial in essential for the formulation of the level of wages through the vote of laws and regulations (Koch, 2005).

We know from the relevant literature that there are sectors of economy pay employees more than other sectors - probably due to high profitability, policy, etc. (Devetter \& Rousseau, 2009). This fact alone may affect the GPD of a state, if this state is operates in sectoral business activities having high profitability.

The main objective of this research is to investigate whether or not there is a research ratio leading to the belief that the Gross Domestic Product (GDP) is a factor contributing (i.e., is directly proportional) to the size of union density. The secondary objective is to examine the type of the correlation between GDP and union density.

The paper is organizedas follows: After the introduction, section two provides an overview of wage inequality between states. The following section deals with the issue of minimum wages and the wage bargaining by trade unions. The fourth section refers to productivity and skills, the business sector and the wages provided. The fifth section examines the role of the state and of collective bargaining. The methodology and results of the research are presented in the sixth section, while the seventh and last section provides the relevant conclusions and recommendations. 


\section{Wage Inequality}

Wage disparities between countries are an indisputable fact (Eurostat, 2014; OECD, 2014). Many researchers have tried to explain why such differences exist and what are the main reasons generating this phenomenon. Blau and Kahn in a survey they conducted found that the objective characteristics of employees were the key differentiating factors (Simon, 2010). A similar survey conducted by Devroye and Freeman concluded that the relevant skills play a minor role in wage inequality and that the key factors are the higher labour market prices and greater residual inequality. In an attempt to explain the phenomenon many researchers have tried to link with low pay with countries with abundance of unskilled workers. However these research findings showed that the indicators used (education and work experience) did not reach this conclusion. Furthermore, the research of Leuven and Oosterbeek, on the same subject concluded that the market and labour demand play the key role in wage differentiation between states.

Another important element in wage inequality is also the way of its adjustment. There is extensive literature documenting and providing explanations on wage adjustments. Institutional explanations assume that collective bargaining and minimum wage adjustments compress wage differences to the bottom of wage distribution in countries with centralized wage determination compared to countries with decentralized wage determination systems. Furthermore, it is known that trade unions generally seek to compress wages and combating of inequality has always been associated with economic benefits (Checchi et al., 2010).

The way in which employees perceive that the remuneration they receive is satisfactory, is also interesting. Employees usually have two criteria to compare the level of their current wages: a) the wages they earned in the past, and b) the wages of other employees (Findlay, 2014). Moreover, Bayo-Moriones et al. (2013) suggest four factors affecting wage adjustment: a) the economic prosperity of the enterprise, b) the operating sector, c) the ability to attract or retain employees, and d) the cost of living.

The relation between the reduction of wage inequality and the existence of strong unions is shown by comparative historical evidence. On the other hand, the claim that wage inequality can be combated by centralization policies and coordination (Vernon, 2015) becomes increasingly weaker. Unionization rates are what seem to explain wage compression and the relation between the two is evident. Vernon and Rogers found that when trade unions are strong there is no noticeable reduction in wages and, furthermore, there is an increase in productivity. Of course, wage inequality varies from state to state and from one job specialization to another. For example Plasman, Rusinek, and Rycx examining the craft industry in Spain, Belgium and Denmark in 1995, revealed that the wage inequality was lower in Spain and Belgium and higher in Denmark. They also found that in Denmark there is a great wage inequality between gender pay gap and white-to blue-collar gap. Later Dell'Aringa and Pagani (Vernom, 2015), confirm Plasman, Rusinek, and Rycx with findings for Spain and Belgium to be similar for Italy. More recent studies (Guertzgen) showed that the demands of trade unions hardly 
affect the level of wages. Rusinek and Rycx, in a survey they conducted for Belgian manual workers, reached similar conclusions.

Naturally, wage inequality is also accompanied by their reduction. Surveys carried out in order to find the causes for the decline of wages (Sen \& Lee, 2015), concluded that it is due to: the growth of the service sector, the disruption of markets and globalization.

\section{Minimum Wage—Demands from Unions}

During the last decades-internationally - the increase of the globalization phenomenon led to a downward spiral of wages and working conditions, especially in businesses aimed at the world market. Wage compression continued and intensified especially in countries with high wages (Glassner \& Pusch, 2013). This led many unions to federate in order to defend their rights, and in some cases to federate and have common requirements at international level.

On the other hand, modern states in an effort to ensure the rule of law and development, promote investment in people, produce added value and try to ensure fairness to citizens. One tool to achieve these objectives could be the introduction of a minimum wage through which would achieve growth and alleviate contrasts. However according to Gokhan-Kocer and Visser (2009), such state intervention tools may not work immediately. The truth is that the effort for an international minimum wage has always been a key objective for the international community. The United Nations Declaration of Human Rights of 1948, for example, states that "everyone who works has the right to just and favorable remuneration ensuring for himself and his family an existence worthy of human dignity" (Article 23, Para. 3). Moreover, the "dream" of a European single minimum wage was always included in the statements of major European politicians: From Joaquin Almunia, Jean-Claude Juncker, former European Commission President Jacques Delors, to PoulNyrup Rasmussen and many others (Schulten, 2008). At least at EU level there is a lack of transnational cooperation for the implementation of a minimum level in European wages. This claim is rather an attempt of cooperation between trade unions thana European policy (Pernicka \& Glassner, 2014).

The introduction of an international minimum wage could be a tool of effective economic policy resulting in macroeconomic and social stability. As regards trade unions, it could provide compensation by increasing prices and granting participation rights in productivity gains (EMF, 1993). This positive impact on economy is usually caused by an increase in productivity (Fanti \& Gori, 2010).

As argued above, a very important role in the formulation of employee remuneration is also played by their demands through the trade unions (Bayo-Moriones et al., 2013). Some academics argued that unions generally support the compression of wages, especially when they need to organize workers of different skill levels and therefore different wages (Checchi et al., 2010). The decline of unionization also - for some researchers - is considered as a major cause for the increase in wage inequality. Card, Lemieux and Riddell, also support that unions can no longer hinder the course of increasing wage inequality especially among men who have different skills and this fact enhances the decline of union 
density in men. The reduced ability of British trade unions to respond to the reduction of wage inequality between men-women and immigrant-native workers is supported by Metcalf, Hansen and Charlwood in a survey they conducted (Checchi et al., 2010).

The contribution of systems is also considered a key factor for wage determination. Many researchers (Plasman et al., 2007) argue that the more central and coordinated the pay system of a country, the smaller the wage differential. Within this framework the two dominant institutional logics that prevail in international literature are: a) the market logic according to which the remuneration of employees is determined by competition and efficient markets, and b) the coordination logic, where the two sides (employers-employees) negotiate in the context of the collective agreement.

The views, however, on the participation of trade unions in the formation of a minimum wage are rather contradictory. Vernon (2015) argues that trade unions affect the level of minimum wages and wages in general, only slightly and always within the frameworks already set by internal labour market structures. In contrast, Cai and Waddoups, in a survey they conducted found that strong unionization and satisfactory employee remuneration are strongly related. Certainly collective bargaining usually helps reduce wage inequalities (Bosch, 2015). This fact may, of course, be accompanied by low rates of union, but nevertheless remains a useful tool in the hands of employees.

\section{Productivity, Wages and Areas of Activity}

It is commonly accepted that new technological applications usually lead to higher productivity and efficiency. Employees with the relevant expertise have, at the same time, the chance to use it to the benefit of the companies employing them. This offers them an advantage of bargaining for higher wages compared to their colleagues who do not have the relevant knowledge (Naticchioni et al., 2008). Moreover, it is an undeniable fact that employees' earnings affect their performance and are an essential tool in the context of Human Resources Management (Findlay et al., 2014).

The proportional relationship between employee performance and the remuneration they receive is indisputable. An important role in this relationship is also played by comparison of wages by employees, something that differentiates their level of effort. This fact makes wage dispersion a very important factor for the performance of employees (Mahy et al., 2011). Nevertheless, the characteristics of this relationship are not clearly defined in theory. Akerlof and Yellen argued that employees will reduce performance if they consider their level of pay is low and that a salary is considered fair if the pay spread is lower than the performance differential. Levine states that proper administration of wages and their proper allocation increase the performance of employees. Hibbs Locking and Milgrom Roberts Martins also reached a similar theoretical approach, as they address the issue of performance-remuneration in a similar manner.

A key role in wage formulation and in the increase of wage inequality is also the sector of activity. Beaumont and Harris, in a survey conducted in the UK, showed that the effect on wage inequality is magnified depending on the sector in which a company operates and that it is also influenced by the 
size and ownership regime.

A key feature of high-skilled employees is that, because they can increase their performance, they should be more extensively paid, which naturally increases the inequality of wages. On the contrary, Foss and Laursen argue that enterprises employing workers with low qualifications have no reason to implement pay-for-performance mechanisms.

\section{The Role of the State and Collective Bargaining}

There is a particular theory in the literature of Industrial Relations which-among other things-attempts to explain the wage setting process. This theory is called "centralization theory" and argues that any regulations on the subject of industrial relations and thus on the issue of wages stem from the settings of the social partners and especially of governments (Park, 2012).

However, in recent years there is a growing trend for wage decentralization with use of variable pay systems. This trend - although its intensity varies from state to state - is constantly rising. Respectively, the system that seems to prevail is the variable pay system with the dominant form of financial reward of groups rather than individuals. Several states, such as Norway, in practice apply a combination of both systems. According to Nergaard, Dolvik, Marginson, Arasanz Diaz and Bechter although in practice the two pay systems coexist in most states, there is a distinct difference between them (Kalmi et al., 2012).

The way in which each state formulates the policy of the provided remunerations and other policies on industrial relations varies. Usually, it includes policies like regulating working hours and minimum wage, passing laws on the requirement for trade union representative and many others. In Sweden, for example, which in 2011 had 67,7 per cent union density (Bosch, 2015) the grant of unemployment benefits is in the hands of trade unions. Local trade unions can also negotiate minimum wages concerning them exclusively, to a level between 50 and 70 per cent of the average wage. In Germany there is no law obliging companies to trade union representation. This fact along with the enactment of the Hartz Law and the consequent reduction in unemployment benefits led to the continuous reduction of union density levels. In the United Kingdom, there was the option of independent collective bargaining or of unilateral agreement between employers and employees. The introduction of a minimum wage in 2007, and subsequently of a statutory national minimum wage in 2015 marked the transition to a new system of direct government intervention in the wage setting process. Furthermore, in Belgium a peculiar system is applied with management of the unemployment insurance scheme, the existence of a minimum wage and the negotiation of a collective agreement being mandatory. In France the minimum wage regime is applied and the additional commitment to respecting collective agreements. However, the fact of strong state intervention in combination with the minimum wage being linked to wages generates resentment and abstention from unionization. 


\section{Research}

\subsection{Research Methodology}

A research was conducted using the statistical package SPSS ver.17 and non-parametric Mann-Whitney test in order to answer the main objective of the research. Moreover, a research was also carried out using the Linear Bivariate Correlation, in order to serve the secondary target of the paper.

As far as Employment and Labour Market Statistics are concerned, data are retrieved from the OECD (Economic Co-operation and Development) website and, particularly, the OECD statistics service as well as the data group: Trade Union Density and National Accounts at a Glance (GDP, Gross Domestic) Product, per head, index using current prices (OECDa, 2015; OECDb, 2015).

\subsubsection{Mann-Whitney Test}

As regards the non-parametric Mann-Whitney test, two variables were created: the first with the name GDP, which groups the 33 countries-members of the OECD, in two categories: wealthy and unprivileged, taking into account the average GDP per head of the last seven years, for which data are available (Table 1).

Table 1. GDP, Gross Domestic Product, per Head, Index Using Current Price

\begin{tabular}{lllllllll}
\hline Country/Year & 2007 & 2008 & 2009 & 2010 & 2011 & 2012 & 2013 & M.O \\
\hline Australia & 109,6 & 106 & 108,4 & 108,9 & 109,6 & 109,3 & 109,4 & 108,7 \\
Slovak Rep. & 59,6 & 64,7 & 66,3 & 67,2 & 66,2 & 66,7 & 66,8 & 65,4 \\
Poland & 53,6 & 56,4 & 59,7 & 63 & 64,7 & 66,8 & 67,4 & 61,7 \\
Korea & 67 & 67,6 & 69 & 70,6 & 71,7 & 72,5 & 72,9 & 70,2 \\
Czech Rep. & 66,7 & 64,3 & 67 & 66,4 & 67,3 & 66,5 & 66,6 & 66,4 \\
Ireland & 102,6 & 97,9 & 93,6 & 93,2 & 89 & 86,3 & 85,3 & 92,6 \\
United Kingdom & 121,5 & 117,7 & 115,9 & 108,2 & 104,6 & 105,3 & 103,9 & 111,0 \\
Netherlands & 114,6 & 116,9 & 116 & 110,2 & 108,2 & 105,7 & 101,9 & 110,5 \\
Hungary & 55,6 & 56,3 & 56,6 & 56,5 & 56,9 & 56,4 & 56,4 & 56,4 \\
Estonia & 58,4 & 58,8 & 53,5 & 53,4 & 54,6 & 57,2 & 58,8 & 56,4 \\
Italy & 96,6 & 98,7 & 98,1 & 99,9 & 97,2 & 93,2 & 90,3 & 96,3 \\
Germany & 104 & 105,3 & 106,6 & 109,4 & 110,9 & 111,8 & 110,6 & 108,4 \\
Turkey & 42 & 44,3 & 44,8 & 48,1 & 51,3 & 50,6 & 51,5 & 47,5 \\
Portugal & 77,8 & 79,1 & 78,8 & 79,3 & 76,5 & 75,7 & 75,5 & 77,5 \\
Austria & 106,7 & 107,7 & 110,1 & 111,2 & 110,2 & 110,1 & 108,5 & 109,2 \\
Canada & 109 & 108,2 & 108,4 & 109 & 108 & 106,3 & 106,8 & 108,0 \\
New Zealand & 86,4 & 87,3 & 88,5 & 88 & 88,5 & 88,3 & 89,8 & 88,1 \\
Belgium & 96,1 & 98,5 & 100 & 100,8 & 101,9 & 102 & 100,7 & 100 \\
Switzerland & 112 & 115 & 117,8 & 116,4 & 115,9 & 117,6 & 117,1 & 116 \\
\hline
\end{tabular}




\begin{tabular}{lllllllll}
\hline Norway & 120 & 120,3 & 122,3 & 122,8 & 120,5 & 122,2 & 121,5 & 121,4 \\
Mexico & 44,9 & 46 & 43,6 & 44,6 & 45,8 & 47 & 47 & 45,6 \\
Finland & 96,9 & 101,2 & 101,9 & 102,3 & 104 & 105,1 & 103,8 & 102,2 \\
Chile & 41,9 & 43,5 & 43,8 & 46,9 & 52,1 & 55 & 57,5 & 48,6 \\
Japan & 93,6 & 92,7 & 94,1 & 95,1 & 95,2 & 97,1 & 97,8 & 95,1 \\
Sweden & 103,9 & 105,6 & 106,5 & 105,4 & 105 & 104,4 & 103,6 & 105,5 \\
Greece & 91,2 & 97,7 & 98,8 & 92,7 & 82,2 & 75,4 & 75,2 & 87,6 \\
Israel & 76,6 & 74,3 & 77,3 & 78 & 79,5 & 80,9 & 81 & 78,3 \\
United States & 149,3 & 147,8 & 147 & 145,9 & 146,2 & 146 & 147,2 & 147,1 \\
Denmark & 102 & 103,9 & 105,2 & 105,2 & 104,4 & 105,4 & 103,6 & 104,2 \\
France & 101 & 101,5 & 102,8 & 103 & 101,8 & 100,8 & 99,3 & 101,5 \\
Iceland & 121,9 & 113,4 & 106,1 & 103 & 103,4 & 105,5 & 105 & 108,3 \\
Luxembourg & 134,7 & 133 & 133,7 & 127,7 & 126,8 & 127,1 & 123,2 & 129,5 \\
Slovenia & 71,8 & 74,1 & 73,7 & 73,4 & 72,6 & 71,2 & 68,4 & 72,2 \\
\hline
\end{tabular}

States with an average over 100 are classified as wealthy and below 100 as unprivileged, while Belgium with an average of 100 is excluded from analysis. The second variable was structured on the basis of data from OECD information on union density for the respective states, but included all years for which data are provided by the same source, namely from 1999 to 2013 with 400 cases in total. To perform the procedure of non-parametric Mann-Whitney test on 2 independent samples (which were created through the first variable), we defined the Monte Carlo method with a confidence interval of $95 \%$.

\subsubsection{Linear Bivariate Correlation}

As regards the Linear Bivariate Correlation and the secondary objective of the research investigation, namely the existence of relationship between Gross Domestic Product and union density, two variables were also created: The first variable is composed of the values of GDP each year for which information on the Gross Domestic Product is available in Table 1 (OECD Statistics, 2015) and the second variable is the rate of union density of the corresponding period (OECDa, 2015; OECDb, 2015).

\subsection{Findings-Results}

6.2.1 Findings-Results of Mann Whitney Test

\section{Table 2. Ranks}

\begin{tabular}{llll}
\hline Gross Domestic Product & N & Mean Rank & Sum of Ranks \\
\hline Trade Union Density wealthy & 200 & 255.95 & 51190.00 \\
unprivileged & 200 & 145.05 & 29010.00 \\
Total & 400 & & \\
\hline
\end{tabular}


Table 3. Test Statistics

\begin{tabular}{ll}
\hline & Trade Union Density \\
\hline Mann-Whitney U & 8910.000 \\
Wilcoxon W & 29010.000 \\
Z & -9.592 \\
Assymp. Sig. (2-tailed) & 0.000 \\
Monte Carlo Sig.Sig. & $0.000^{\mathrm{a}}$ \\
(2-tailed) 95\% Confidence Lower Bound & 0.000 \\
Interval Upper Bound & 0.000 \\
Monte Carlo Sig. Sig. & $0.000^{\mathrm{a}}$ \\
(1-tailed) 95\% Confidence Lower Bound & 0.000 \\
Interval Upper Bound & 0.000 \\
\hline
\end{tabular}

a. Based on 10000 sampled tables with starting seed 2000000 .

b. Grouping Variable: Gross Domestic Product.

Table 3 gives us enough information and of course, it helps us to reach the conclusion of the first objective of the research, namely whether states with high GDP have ranked higher union density over time. At this point, we have to formulate the null hypothesis and our alternative hypothesis. The main factor for its formation is whether or not there is a research ratio leading to the impression that a high product per capita is a factor contributing (is directly proportional) to the density and size of union density. Indeed, Table 2 suggests this as wealthy countries have an average 255.95 while unprivileged countries 145.05 , which obliges us to choose to examine the null hypothesis by the directional approach (1- tailed test):

$\mathrm{H}_{0}=$ There is no difference in the two samples of states, regarding union density,

$\mathrm{H}_{1}=$ The union density rate is higher for the group of wealthy countries.

Because the observed level of statistical significance is in accordance with the Monte Carlo method at a $95 \%$ confidence level (1-tailed) $=0,000$ namely $1 \%$ which is less than $5 \%$, our null hypothesis is rejected in favor of the alternative hypothesis $\mathrm{H}_{1}$. We therefore conclude that there is a statistically significant difference in favor of the first group of states with regard to union density. Moreover, the conclusion in terms of labour relations is that the larger the GDP of a country, the proportionately higher the union density in the country.

6.2.2 Findings-Results of Linear Bivariate Correlation

Table 4. Correlations

Gross

Density

Domestic Product

in Unions 


\begin{tabular}{lllc}
\hline & Pearson Correlation & 1 & $.401\left(^{* *}\right)$ \\
Gross Domestic Product & Sig. (1-tailed) &. & .000 \\
& $\mathrm{~N}$ & 200 & 200 \\
& Pearson Correlation & $.401\left(^{* *}\right)$ & 1 \\
UnionDensity & Sig. (1-tailed) & .000 &. \\
& $\mathrm{~N}$ & 200 & 200 \\
\hline
\end{tabular}

Table 4 presents the results of the Linear Bivariate Correlation. At this point we must note the following, regarding the conduct of the test.

1) Of the three available correlation coefficients we preferred to use the Pearson coefficient, as the data of the two variables are numeric.

2) As regards the test of Significance we chose the directional approach, namely the One-tailed test, as we found that there is a positive relationship between the two variables (when the Gross Domestic Product rises, union density rises too, while when reducing, the other variable is respectively reduced). This means that the function is monotonic and therefore there is no need to perform a two-tailed test, but a one-tailed instead.

3) We chose $1 \%$ as level of statistical significance of $1 \%$, in an effort to tighten the test.

The null and alternative hypotheses were formulated as follows:

$\mathrm{H}_{0}=$ The Gross Domestic Product and union density variables have no linear correlation;

$\mathrm{H}_{1}=$ The Gross Domestic Product and union density variables have linear correlation.

Regarding Table 4 and the results obtained we can observe the following:

1) The Pearson indicator is marked with asterisks which means that it received a statistically significant value (positive value 0.401 ) which is between 0.5 (strong) and 0.3 (medium), and is thus considered as relatively strong with positive correlation (the values of a variable "follow" the values of the other), (Cohen, 1988). This correlation is significant at a level of significance of $1 \%$.

2) The observed level of statistical significance for a single direction is 0.0005 and therefore much less than that set as threshold for testing the null hypothesis, namely $1 \%$. Consequently, the null hypothesis is rejected in favor of the alternative hypothesis.

1) Test of Normality of Linear Bivariate Correlation. 


\section{Normal Q-Q Plot of Gross Domestic Product}

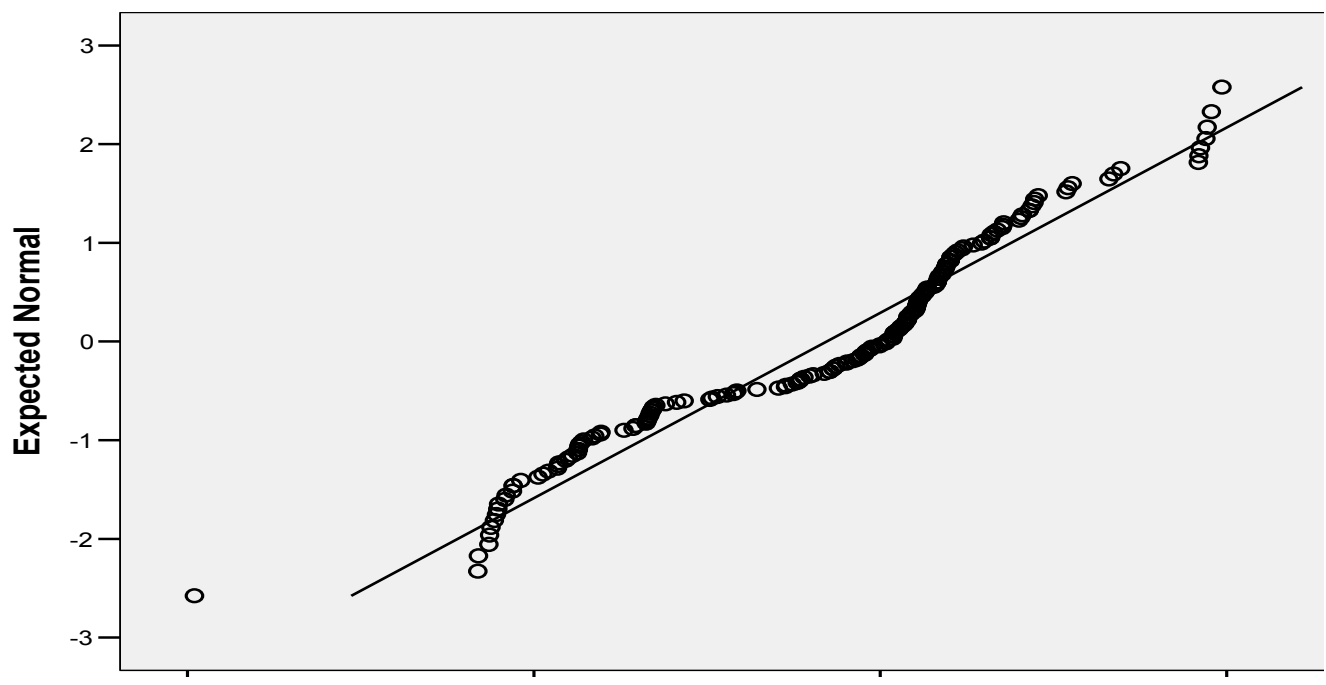

Figure 1. Regularity Test of the Gross Domestic Product Variable

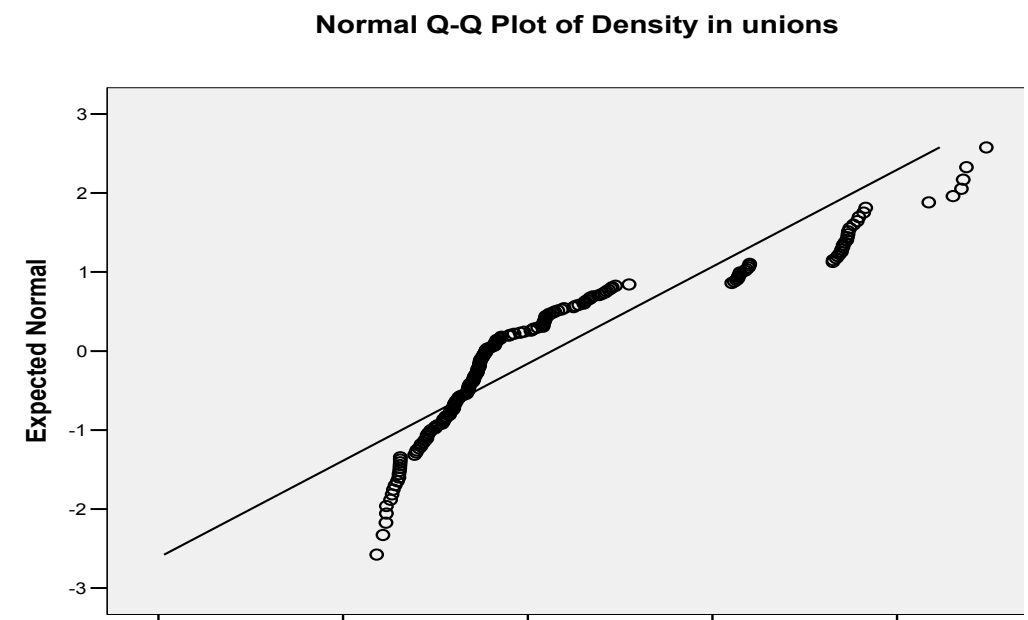

Figure 2. Regularity Test of the Union Density Variable

As regards the regularity of the Gross Domestic Product variable (Table 5) and Union Density variable (Table 6) I observe that to a fairly large extent dots representing the actual and expected values of two variables "hover" the bisector of the axes, approach it, tend to coincide with it and a very significant proportion of them actually meet said bisector. In this case and especially for research in the area of Social Sciences -the distributions of two variables of the sample are considered to approximate normal. 


\section{Conclusions-Proposals}

The main purpose of this paper was to investigate the existence of a research index which would lead us to believe that GDP is a factor proportional to the size of union density. The findings showed that high GDP contribute (is directly proportional) to the size of the union density and hence, the higher the GDP of a country, the higher its union density.

The secondary objective of this research was to examine the type of correlation between Gross Domestic Product and Union Density. The findings showed the existence of a moderately strong positive correlation between the two variables, which means that the values of one variable follow the prices of the other on a parallel increase, decrease or stability.

It should be clarified that although the results of this research serve the purpose of this paper, they cannot be generalized due to the relatively small number of cases which stems from the research limitation for existence of GDP and Union Density, in the same periods. Thus, broader investigation should be carried out with the help of other information and, possibly, of other international organizations. However, the observed continuing decline in the levels of trade unionism and the remuneration of employees does not indicate a good future for Industrial Relations.

\section{References}

Benoît, M., Rycx, F., \& Volral, M. (2011). Wage Dispersion and Firm Productivity in Different Working Environments. British Journal of Industrial Relations, 49(3), 460-485. https:/doi.org/10.1111/j.1467-8543.2009.00775.x

Bosch, G. (2015). Shrinking collective bargaining coverage, increasing income inequality: A comparison of five EU countries. International Labour Review, 154(1), 57-66. http://dox.doi.org/10.1111/j.1564-913X.2015.00231.x

Buttigieg, M., Donna, D., Stephen, J., \& Iverson, D. R. (2008). Union Mobilization: A Consideration of the Factors Affecting the Willingness ofUnion Members to Take Industrial Action. British Journal of Industrial Relations, 46(2), 248-267. http://dox.doi.org/10.1111/j.1467-8543.2008.00675.x

Checchi, D., Visser, J., \& Van de Werfhorst, G., H. (2010). Inequality and Union Membership: The Influence of Relative Earnings and Inequality Attitudes. British Journal of Industrial Relation, 48(1), 84-108. http://dox.doi.org/10.1111/j.1467-8543.2009.00757.x

Cohen, J. (1988). Statistical Power Analysis for the Behavioral Sciences (2nd ed.). Hillsdale NJ: LEA.

Devetter, François-Xavier, \& Rousseau, S. (2009). The Impact of Industrialization on Paid Domestic Work: The Case of France. European Journal of Industrial Relations, 15(3), 297-316. http://dox.doi.org/10.1177/0959680109339414

EMF. (1993). Collective Bargaining Policy in a Changing Europe. Statement of principle on Collective Bargaining. The 1st EMF Collective Bargaining Conference, Luxembourg, March.

Eurostat. (2014). Employment in Europe 2014. Luxembourg: Office for Official Publications of the European Communities. 
Fanti, L., \& Gori, L. (2010). Economic Growth and Welfare in a Neoclassical Overlapping Generations Growth Model with Minimum Wages and Consumption Taxes. Labour, 24(3), 238-262. Retrieved form http://www.pdflib.com

Findlay, J., Findlay, P., \& Stewart, R. (2014). Occupational pay comparisons-Easier said than done? Employee Relations, 36(1), 2-16. http://dox.doi.org/10.1108/ER-05-2013-0056

Glassner, V., \& Pusch, T. (2013). Towards a Europeanization of wage bargaining? Evidence from the metal sector. European Journal of Industrial Relations, 19(2), 145-160. http://dox.doi.org/10.1177/0959680113482209

Gökhan-Koçer, R., \& Visser, J. (2009). The Role of the State in Balancing the Minimum Wage in Turkey and the USA. British Journal of Industrial Relations, 47(2), 349-370. http://dox.doi.org/10.1111/j.1467-8543.2009.00730.x

Kalmi, P., Pendleton, A., \& Erik, P. (2012). Bargaining regimes, variable pay and financial participation: some survey evidence on pay determination. The International Journal of Human Resource Management, 23(8), 1643-1659. http://dox.doi.org/10.1080/09585192.2012.661993

Kaufman, E., \& Bruce. (2008). Paradigms in Industrial Relations: Original, Modern and Versions In-between. British Journal of Industrial Relations, 46(2), 314-339. http://dox.doi.org/10.1111/j.1467-8543.2008.00676.x

Koch, M. (2005). Wage Determination, Socio-Economic Regulation and the State. European Journal of Industrial Relations, 11(3), 327-346. http://dox.doi.org/10.1177/0959680105057214

Morentin, S. (2013). The determinants of pay settlements: The influence of the national context. The International Journal of Human Resource Management, 24(3), 579-600. http://dox.doi.org/10.1080/09585192.2012.694110

Naticchioni, P., Ricci, A., \& Rustichelli, E. (2008). Wage Inequality, Employment Structure and Skill-biased Change in Italy. LABOUR (Special Issue), 22, 27-51. Retrieved form http://www.pdflib.com

OECD. (2014). Employment Outlook 2014. Paris: OECD Publications.

OECDa.

Retrieved

from

http://www.oecd-ilibrary.org/employment/oecd-labour-force-statistics_23083387

$O E C D b$. (2015). Retrieved from http://www.stats.oecd.org/

Park, S. H. (2012). Capital openness, monetary integration, and wage-setting coordination in developed European countries. Economic and Industrial Democracy, 34(4), 637-666. http://dox.doi.org/10.1177/0143831X12452944

Pernicka, S., \& Glassner, V. (2014). Transnational trade union strategies towards European wage policy: A neo-institutional framework. European Journal of Industrial Relations, 20(4), 317-334. http://dox.doi.org/10.1177/0959680113518232

Piore, J., \& Michael. (2011). Whither Industrial Relations: Does It Have a Future in Post-Industrial Society? British Journal of Industrial Relations, 49(4), 792-801. 
http://dox.doi.org/10.1111/j.1467-8543.2011.00880.x

Plasman, R., Rusinek, M., \& Rycx, F. (2007). Wages and the Bargaining Regime under Multi-level Bargaining: Belgium, Denmark and Spain. European Journal of Industrial Relations, 13(2), 161-180. http://dox.doi.org/10.1177/0959680107078251

Prosser, T. (2014). Financialization and the reform of European industrial relations systems. European Journal of Industrial Relations, 20(4), 351-365. http://dox.doi.org/10.1177/0959680113505178

Schulten, T. (2008). Towards a European Minimum Wage Policy? Fair Wages and Social Europe. $\begin{array}{lllll}\text { European Journal of Industrial Relations, 14(4), 421-439. } & \text {. }\end{array}$ http://dox.doi.org/10.1177/0959680108097494

Sen, R., \& Lee, Chang-Hee. (2015). Workers and social movements of the developing world: Time to rethink the scope of industrial relations? International Labour Review, 154(1), 37-45. http://www.ilo.org/global/lang--en/index.htm

Simón, H. (2010). International Differences in Wage Inequality: A New Glance with European Matched Employer-Employee Data. British Journal of Industrial Relations, 48(2), 310-346. http://dox.doi.org/10.1111/j.1467-8543.2008.00708.x

Vernon, G. (2015). Does egalitarian pay add value? Pay compression, union structure and manufacturing productivity growth in the OECD. European Journal of Industrial Relations, 21(1), 73-91. http://dox.doi.org/10.1177/0959680113511007

Williams, C., Colin, K. A., Nadin, S., \& Vorley, T. (2013). Evaluating the extent and nature of the in formalization of employment relations in South-East Europe. European Journal of Industrial Relations, 19(2), 91-107. http://dox.doi.org/10.1177/0959680113481732 